Accessed on: http://jkb.ub.ac.id/index.php/jkb/article/view/2493

Jurnal Kedokteran Brawijaya Vol. 31, No. 1, Februari 2020, pp. 43-48

Article History: Received 27 November 2018, Accepted 10 September 2019

Research Article

\title{
Relationship of TTF-1 and EGFR on Lung Adenocarcinoma at Dr. Saiful Anwar General Hospital Malang
}

\section{Hubungan Ekspresi TTF-1 dan Mutasi EGFR pada Adenokarsinoma Paru di RSUD Dr. Saiful Anwar Malang}

\author{
Andy ${ }^{1}$, Suryanti Dwi $P^{2}$, Ngakan Putu $P^{3}$, Eviana Norahmawati $i^{4}$ Harun Al Rasyid ${ }^{5}$ \\ ${ }^{1,2,3}$ Department of Pulmonary and Respiratory Medicine Dr. Saiful Anwar Hospital Malang \\ ${ }^{4}$ Department of Anatomical Pathology Faculty of Medicine Universitas Brawijaya Malang \\ ${ }^{5}$ Department of Public Health Sciences Faculty of Medicine Universitas Brawijaya Malang
}

\begin{abstract}
There is a correlation between mutation of Epidermal Growth Factor Receptor (EGFR) and lung adenocarcinoma. Unfortunately, examination for EGFR mutation is difficult because surgery must be conducted to obtain the best specimen. Thyroid Transcription Factor-1 (TTF-1) is a marker for lung adenocarcinoma. This observational study took place at Dr. Saiful Anwar Hospital from stored biological materials from 2013-2018. Samples were lung adenocarcinoma patients that undergo EGFR examination. Data then analyzed using Fischer's Exact Test to determine the relationship between EGFR and TTF-1. Specificity/sensitivity value is $0.75 / 0.90, p: 0.617$, odds ratio 0.333 (0.032-3.515). However, Receiver Operating Characteristic (ROC) curve of TTF- 1 show AUC 0.614 (95Cl, 0.35- 0.878). TTF-1 examination has a moderate strength in determining EGFR mutation on lung adenocarcinoma patients at Dr. Saiful Anwar Hospital.
\end{abstract}

Keywords: Epidermal Growth Factor Receptor (EGFR), lung adenocarcinoma, Thyroid Transcription Factor-1 (TTF-1)

\section{ABSTRAK}

Terdapat korelasi antara mutasi Epidermal Growth Factor Receptor (EGFR) dan adenokarsinoma paru. Namun, pemeriksaan untuk mutasi EGFR sulit karena spesimen yang baik berasal dari pembedahan. Thyroid Transcription Factor-1 (TTF-1) adalah marker untuk adenokarsinoma paru. Penelitian observasional ini bertempat di RSUD Dr. Saiful Anwar Malang dari bahan biologi tersimpan sejak tahun 2013 sampai dengan pertengahan tahun 2018. Sampel adalah pasien yang didiagnosa dengan adenokarsinoma paru yang telah dilakukan pemeriksaan EGFR. Data kemudian dianalisis dengan Fischer's exact test untuk menentukan hubungan antara EGFR dan TTF-1. Nilai spesifisitas/sensitifitas adalah 0,75/0,90, p: 0,617, odds rasio 0,333 (0,032-3,515). Namun, kurva Receiver Operating Characteristic (ROC) dari TTF-1 menunjukkan Area Under Curve (AUC) 0,614 (95Cl, 0,35- 0,878). Pemeriksaan TTF-1 memiliki kekuatan sedang dalam menentukan mutasi EGFR pada pasien adenokarsinoma paru di RSUD Dr. Saiful Anwar Malang.

Kata Kunci: Adenokarsinoma paru, Epidermal Growth Factor Receptor (EGFR), Thyroid Transcription Factor-1 (TTF-1)

Correspondence: Andy. Department of Pulmonary and Respiratory Medicine Dr. Saiful Anwar Hospital, Jl. Jaksa Agung Suprapto No. 2, Malang Tel.082244335732 Email:andylumbangaol85@gmail.com

DOI: http://dx.doi.org/10.21776/ub.jkb.2020.031.01.9 


\section{INTRODUCTION}

Lung cancer, in a broad meaning, is all malignancies in the lungs, including those originating from the lungs and outside the lungs (metastatic tumor in the lungs). Lung cancer is divided into two main types that are Small-Cell Lung Cancer (SCLC) and Non-Small-Cell Lung Cancer (NSCLC). NSCLC constitutes $80 \%$ of all lung cancers with adenocarcinoma as the most common type of histology (1).

The tendency of the number of thoracic malignancy cases keeps increasing, especially in referral hospitals such as Persahabatan Hospital Jakarta, Dr. Soetomo Hospital Surabaya, and Dharmais Cancer Hospital Jakarta. Similarly, the same trend also occurs in other pulmonology education centers, such as in Dr. Saiful Anwar General Hospital Malang, Moewardi General Hospital Solo, Dr. M. Djamil General Hospital Padang, and Adam Malik General Hospital Medan. In the thoracic malignancy group, which consists of lung cancer, mediastinal tumors, mesotheliomas, tumor metastases in the lung, and chest wall tumors, the incidence of lung cancer remains the highest case (2).

Approximately $60 \%$ of NSCLC patients are diagnosed when the disease is at the advanced stage. The available therapies nowadays are surgery, radiotherapy, and chemotherapy, which are given based on the stage of the patient's lung cancer. Administration of chemotherapy alone or in combination with other therapeutic modalities such as radiotherapy or surgery gives unsatisfactory results in improving the patients' quality of life. Also, the presence of toxicity and resistance to chemotherapy drugs limits the use of therapy. Recent research has found that there are genetic disorders that play a role in controlling cell survival. These deviations increase cell division and induce the occurrence of tumors. One pathway that can experience deviation is the Epidermal Growth Factor Receptor (EGFR). EGFR is a transmembrane receptor tyrosine kinase protein that can be found in normal epithelium, mesenchymal, and neurogenic tissue. Excessive expression of EGFR is thought to play a role in the development of lung cancer (1).

Mutations that occurred in EGFR are mostly found among Asian ethnic and adenocarcinoma lung cancer patients at around $51.4 \%$, while gender and smoking status are found insignificantly associated with these mutations. Through the discovery of EGFR examination and the development of target therapies in EGFR mutations, the duration and quality of life of adenocarcinoma patients are greatly improved. However, there are limitations in detecting mutations in EGFR. The best specimens for EGFR mutation examination are obtained from surgery, but $70-80 \%$ of NSCLC patients cannot undergo surgery when diagnosed. Besides, the biopsy also provides a high risk of bleeding in the advanced cancer stage. Therefore, some patients do not get effective and timely treatment, so it is necessary to find an efficient alternative indicator of EGFR mutation status (3).

In the histopathological examination, it is often found difficult to ascertain the histological type of lung cancer, especially from small biopsy materials and cytological preparations. In this situation, additional tests such as immunohistochemical (IHC) examination are needed to help confirm the type of lung cancer. Some data indicate that the diagnosis of adenocarcinoma or squamous cell carcinoma can be established in $50-70 \%$ of cases only by morphological examination of small biopsy preparations or cytology. IHC staining can help determine the histological type up to the subtypes so that the final diagnosis is not only Non-Small-Cell Lung Cancer but also up to the subtype (4).

Based on the latest WHO classification in 2015, the common markers used for adenocarcinomas are Thyroid Transcription Factor-1 (TTF-1) and Napsin A with positivity degrees depending on the histological subtype (80\% sensitivity rate). TTF-1 is a member of the NKX2-1 family. TTF-1 is expressed in the thyroid, forebrain, lungs, and other organs. In the lung, TTF-1 is mainly present in type II alveolar epithelial cells and non-ciliated bronchial epithelial cells.

Both increasing surface active substance and secretory protein region of the Clara cells have a binding site that can maintain lung cancer cell activity. TTF-1 in pulmonary adenocarcinoma has been thoroughly described and is considered a specific marker of pulmonary adenocarcinoma. The histological features of adenocarcinoma vary widely and become a problem when the differential diagnosis includes metastases or malignant mesotheliomas. In a clinical study in the New England Journal (NEJ) in 2010, it was explained that in patients with pulmonary adenocarcinoma positive for TTF-1 expression, the rate of EGFR mutations was higher. Particularly, Asians, women, and non-smokers have significantly higher levels of TTF-1 expression and EGFR mutations (4).

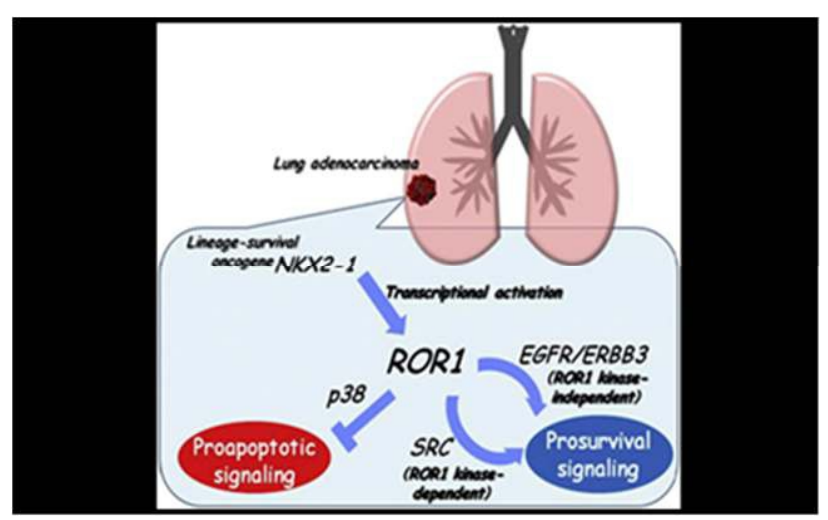

Image 1. Relationship between EGFR and TTF-1

A study identified NKX2-1, also known as TITF1 and TTF-1, as hereditary survival oncogenes in pulmonary adenocarcinoma. It was explained that NKX2-1 induces the expression of the tyrosine receptor kinase-like receptor orphan 1 (ROR1), which in turn sustains an advantageous balance between PI3K-AKT pro-survival and p38 proapoptotic signaling, some through activation of c-Srcdependent ROR1 and supporting independent activity kinases from the association EGFR-ERBB3, ERBB3 phosphorylation, and consequential activation of PI3K. Distinctively, ROR1 knockdown effectively inhibits pulmonary adenocarcinoma cell lines, regardless of their EGFR status, including those that are resistant to EGFR gefitinib tyrosine kinase inhibitors. This finding identifies ROR1 as a therapeutic strategy for future cancers in pulmonary adenocarcinoma (5). 
Until recently, no research has been conducted at Dr. Saiful Anwar General Hospital Malang regarding the relationship between TTF-1 expression and EGFR mutations in pulmonary adenocarcinoma patients. Therefore, this study examines the relationship between TTF-1 expression and EGFR mutations in pulmonary adenocarcinoma patients at Dr. Saiful Anwar General Hospital Malang, so it is expected to be a consideration for patients to receive EGFR-TKI (Epidermal Growth Factor Receptor - Tyrosine Kinase Inhibitor) for patients who cannot carry out EGFR mutation examination. It is hoped that it facilitates patients to get appropriate therapy.

\section{METHOD}

The type of this research was descriptive-analytic research. The study was conducted on stored biological materials in patients with pulmonary adenocarcinoma in the Anatomy Pathology laboratory of Dr. Saiful Anwar General Hospital Malang. Samples were patients with pulmonary adenocarcinoma, namely malignant epithelial tumor with gland differentiation, mucin production, or expression of pneumocyte markers, and had undergone EGFR mutation examination in the pulmonary outpatient care or inpatient department of Dr. Saiful Anwar General Hospital Malang from 2013 to the middle of 2018. Data were taken from pulmonary adenocarcinoma patients who had undergone EGFR mutation examinations before therapy.

There were two variables used in this study, namely: (1) EGFR mutation, in which there are gene changes (mutations, insertions, and deletions) in patients with pulmonary adenocarcinoma; and (2) TTF-1 expression. The pathological diagnosis was considered definite if the identified TTF-1 was expressed in the nucleus. Samples were considered negative if TTF-1 expression in positive tumor cells was $0-10 \%$, partially positive if $10-50 \%$ positive, and positive (+) if more than $50 \% \mathrm{p}$

ositive tumor cells were found TTF-1 expression. The inclusion criteria were stored biological materials of patients diagnosed with CBNBS type adenocarcinoma by pathology anatomy examination, stored biological materials of pulmonary adenocarcinoma patients who have never received anticancer treatment, stored biological materials of pulmonary adenocarcinoma patients aged more than 18 years, stored biological materials of pulmonary adenocarcinoma patients examined by EGFR derived from histopathological tissue material and biopsy (FOB) in the form of paraffin blocks. While the exclusion criteria were if two cancers were found in a place other than the lungs, and stored biological materials of pulmonary adenocarcinoma patients examined by EGFR derived from histopathological tissue material and biopsy (FOB) in the form of paraffin blocks contained no malignant cells.

Examination of GFR mutations was carried out by isolating DNA from tumors using the Micro DNA QIAamp kit (Qiagen, Hilden, Germany) by following the manufacturer's protocol. DNA from each sample was eluted in 50 $\mathrm{L} \mathrm{AE}$ buffer (included in the kit). Exon 19 and 21 EGFR mutation screenings were performed using PCRHRM (Polymerase Chain Reaction - High-Resolution Melt) analysis. PCR-HRM analysis was performed on Rotor-Gene $Q$ (Qiagen) using an SYTO9 intersection dye (Thermo Fisher Scientific Inc., Waltham, MA, USA). The samples were denatured with an initial hold of $95^{\circ} \mathrm{C}$ for 30 seconds and the melting profile from $79^{\circ} \mathrm{C}$ to $90^{\circ} \mathrm{C}$ increased at $0.2^{\circ} \mathrm{C}$. HRM data were presented as a derivative graph for observing "split peaks," which showed the existence of mutated alleles (Figure 2) by using the Rotor-Gene $Q$ (Qiagen) software. The peak split pattern was observed in a low percentage of mutant alleles, which was less than $25 \%$, a percentage that usually cannot be detected using the Direct Sequencing method. The PCR-RFLP (Polymerase Chain Reaction-Restriction Fragment Length Polymorphism) method was then used to follow up the alleged mutations in the presence of a "split peak" pattern. The L858R EGFR genotyping and L861Q hotspot mutation on exon 21 were performed using PCR-RFLP which has
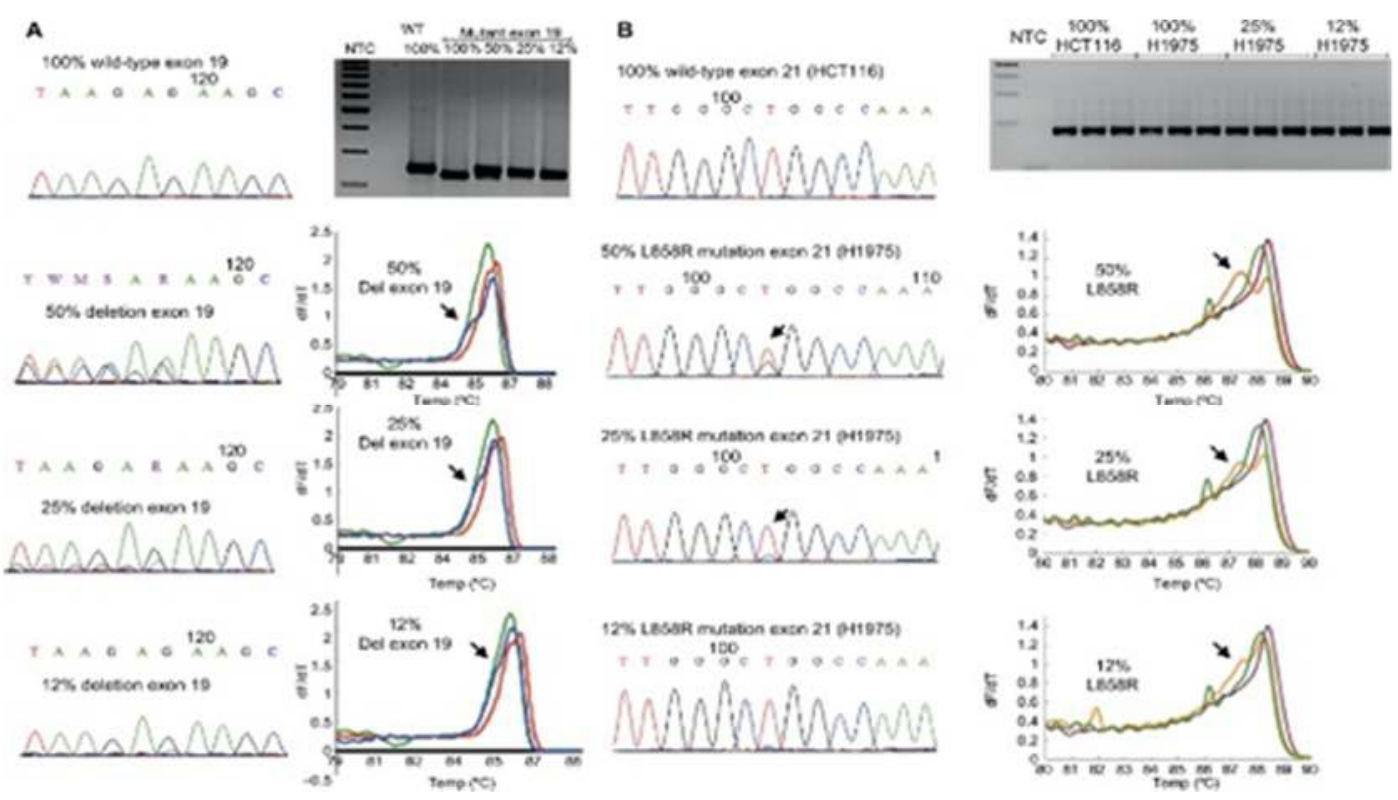

Figure 2. Analytical sensitivity of the PCR-HRM chart. Melt pattern graphs (right panel (B)) compared to direct sequencing (left panel (A)) and size of the fragments to the screen for mutation insertion/deletion in the exon 19 EGFRgene (A) and L858R point mutation in exon 21 (B) 
been proven to detect $1 \%$ of mutant alleles. Mutations in exon 18 EGFR (to detect G719X) and 20 (T790M and insertions) were analyzed using Sanger Sequencing. Some samples carrying mutations in the exon 20 T790M were retested using the Therascreen RGQ RGQ EGFR kit (Qiagen, Manchester, UK) or AmoyDx Detection of the 29 EGFR mutation kits (AmoyDx, Xiamen, China) (3).

The approach selected in this study was cross-sectional to determine the relationship between TTF-1 expression and EGFR mutations tested using Chi-square, with a 95\% confidence level, $\alpha=0.05$. Results were declared significant if $p<0.05$. The diagnostic test results were stated in a $2 \times 2$ table, and then the sensitivity, specificity, accuracy, positive predictive value, and negative predictive value were calculated.

TTF-1 examination was based on SOP of Immunohistochemical Examination of Anatomical Pathology Installation Dr. Saiful Anwar General Hospital. Materials or preparations were delivered to the technician department for processing in the next day, and then the preparations were cut with microtone as thick as 4 to 5 microns. They were attached to the glass object that had been coated with Poly L-Lysin (please pay attention to the numbering of the preparations and the name of the antibody, the length of time in the waterbath, $56-57^{\circ} \mathrm{C}$ waterbath temperature) and stored in a $40^{\circ} \mathrm{C}$ incubator overnight, so it attached more firmly (before the staining process, they were dried and heated on a hot plate for 1 hour). Deparaffinization was done with Xylol I, II, III for 3 minutes each. Put into ethanol, $90 \%$ alcohol, $80 \%$ for $2-3$ minutes each. Put into $\mathrm{H} 2 \mathrm{O} 2$ in methanol $0.5 \% 100 \mathrm{ml}$ methanol $+1.6 \mathrm{ml} \mathrm{H} 2 \mathrm{O} 2$ for 20 minutes. Retrieval antigen was soaked in DIVA solution and heated in Decloaking Chamber. Cooled at room temperature 20 to 30 minutes (rinsed with distilled water). Soaked in Phosphate Buffer Copy (PBS) for 2-5 minutes. Placed the slide in a moisture chamber and put a barrier around the preparation with a pap pen. Dripped with sniper background for 10-15 minutes. Dripped with the primary antibody and incubated for 10 minutes. Washed hands for 2-5 minutes. Dripped with the secondary antibody and incubated for 10 minutes. Washed hands for 2-5 minutes. Dripped with the Trekavidin-Hrp Label and incubated for 10 minutes. Washed hands for 2-5 minutes. Dripped the DAB and incubated for 2-4 minutes (1 ml of Betazoid Dab Substrate Buffer plus 1-2 drops of Chromogen DAB). Washed with running water for 5-7 minutes. Counterstain with mayers hematoxylin for 2-3 minutes (soaked in saturated lithium Carbonate 2-3 minutes). Washed with running water for 5-7 minutes. Dehydrated with $80 \% 96 \%$ alcohol, absolute alcohol up to xylol I, II, III for 3 minutes each. Mounted with Entellan.

\section{RESULTS}

Data processing in this study was conducted in September to October 2018, and secondary data were taken from the medical records of lung cancer patients treated at the Pulmonology department of Dr. Saiful Anwar General Hospital Malang. To find out the frequency of EGFR mutations, data were taken from the medical records of patients who underwent EGFR examinations from 2013 to the middle of 2018. To see the relationship between EGFR mutations and TTF-1 levels, secondary data were taken from 26 medical records that met the inclusion criteria.
Table 1. Characteristics of research subjects

\begin{tabular}{lc}
\hline \multicolumn{2}{c}{ Variable } \\
\hline Age & N: $\mathbf{2 6}$ \\
Mean & 56,1 \\
$<65$ years & $21(80,8 \%)$ \\
$\geq 65$ years & $5(19,2 \%)$ \\
Gender & $\mathbf{N}: \mathbf{2 6}$ \\
Male & $19(73,1 \%)$ \\
Female & $7(26,9 \%)$ \\
\hline
\end{tabular}

At the TTF-1 examination, of the total research subjects that were 26 people, samples with positive TTF-1 were 21 people (80.8\%), and TTF-1 negative were 5 people (19.2\%). The frequency of TTF- 1 in the study is shown in Table 2.

Table 2. Results of the TTF-1 examination

\begin{tabular}{lr}
\hline \multicolumn{2}{c}{ Variable } \\
\hline TTF - 1 & N: $\mathbf{2 6}$ \\
Positive & $21(80,8 \%)$ \\
Negative & $5(19,2 \%)$ \\
EGFR & \\
Mutation & $16(61.5 \%)$ \\
Wildtype & $10(38.5 \%)$ \\
\hline
\end{tabular}

Based on the results of the medical record recapitulation, the results of the EGFR mutation examination are shown in Table 3.

Result show that 16 patients experienced EGFR mutations out of 26 patients (61.5\%).

Table 3. Results of EGFR mutation examination

\begin{tabular}{ll}
\multicolumn{2}{c}{ Variable } \\
\hline EGFR & N: $\mathbf{2 6}$ \\
Mutation & $16(61.5 \%)$ \\
Wildtype & $10(38.5 \%)$ \\
\hline
\end{tabular}

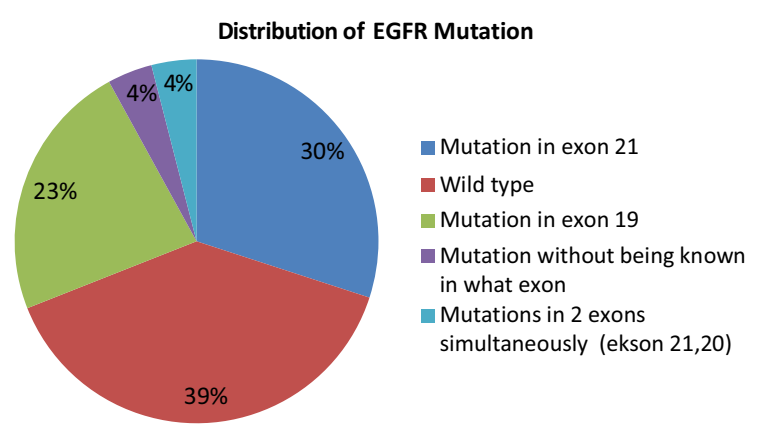

Figure 3. Diagram of the percentage of EGFR status in patients with Adenocarcinoma lung cancer at Dr. Saiful Anwar General Hospital Malang.

From the classification of these mutations, 8 people have 
mutations in exon 21, 6 people have mutations in exon 19 , 1 person has a mutation in 2 exons simultaneously (exon $21,20)$, and 1 person has a mutation without being known in what exon while there were 10 people without mutation or Wildtype. The most mutations are in exon 21 and exon 19. Some samples have mutations in 2 exons simultaneously (exon 21,20).

Table 4. Relationship between EGFR mutations and TTF-1 examination results

\begin{tabular}{lccccc}
\hline & \multicolumn{4}{c}{ EGFR } & \multirow{2}{*}{ p } \\
\cline { 2 - 5 } TTF - 1 & \multicolumn{2}{c}{ Mutation } & \multicolumn{2}{c}{ Wildtype } & \\
\cline { 2 - 5 } & $\mathbf{N}$ & $\mathbf{\%}$ & $\mathbf{N}$ & $\%$ & \multirow{2}{*}{0,614} \\
\hline Positive & 12 & $46,20 \%$ & 9 & $34,60 \%$ & \\
Negative & 4 & $15,40 \%$ & 1 & $3,80 \%$ & \\
\hline
\end{tabular}

Table 4 shows that 26 people were divided into four groups, namely 1 wildtype patient with negative TTF-1 examination, 9 wildtype patients with positive TTF-1 result, patients with EGFR mutation with TTF-1 results negative as many as 4 people, and patients with EGFR mutations with TTF-1 positive results as many as 12 people.

Table 5. Odd mutation ratio of EGFR and TTF-1

\begin{tabular}{|c|c|c|c|}
\hline & \multirow{2}{*}{ Value } & \multicolumn{2}{|c|}{$\begin{array}{l}\text { 95\% Confidence } \\
\text { Interval }\end{array}$} \\
\hline & & Lower & Upper \\
\hline Odds Ratio for TTF-1 (Positive / Negative) & 0.333 & 0.032 & 3.515 \\
\hline For cohort EGFR = Positive & 0.714 & 0.402 & 1.268 \\
\hline For cohort EGFR = Negative & 2.143 & 0.347 & 13.242 \\
\hline $\mathrm{N}$ of Valid Cases & 26 & & \\
\hline
\end{tabular}

Based on the Chi-square test, there was no significant relationship between the results of TTF-1 examination with EGFR mutations ( $p: 0.614)$.

Table 6. Distribution of samples at TTF-1 examination and EGFR

\begin{tabular}{ccccc}
\hline \multirow{2}{*}{ TTF - 1 } & \multicolumn{4}{c}{ EGFR } \\
\cline { 2 - 5 } & \multicolumn{3}{c}{ Mutation } & \multicolumn{3}{c}{ Wildtype } \\
\cline { 2 - 5 } & \multicolumn{2}{c}{$\mathbf{N}$} \\
\hline Positive & 12 & (a) & 9 & (b) \\
Negative & 4 & (c) & 1 & (d) \\
\hline
\end{tabular}

It is known that the sensitivity of the TTF-1 examination is $75 \%$ and the specificity is $10 \%$. From the sensitivity results, it can be concluded that TTF-1 can detect an EGFR mutation as much as $75 \%$. A $10 \%$ specificity result means that the possibility of a TTF-1 examination can detect patients with lung cancer without EGFR mutation as much as $10 \%$. A positive predictive value of $57 \%$ means that only about $57 \%$ of EGFRs are truly mutated. A negative predictive value of $20 \%$ means that about $20 \%$ of EGFR adenocarcinoma lung cancer patients have absolutely no mutations.

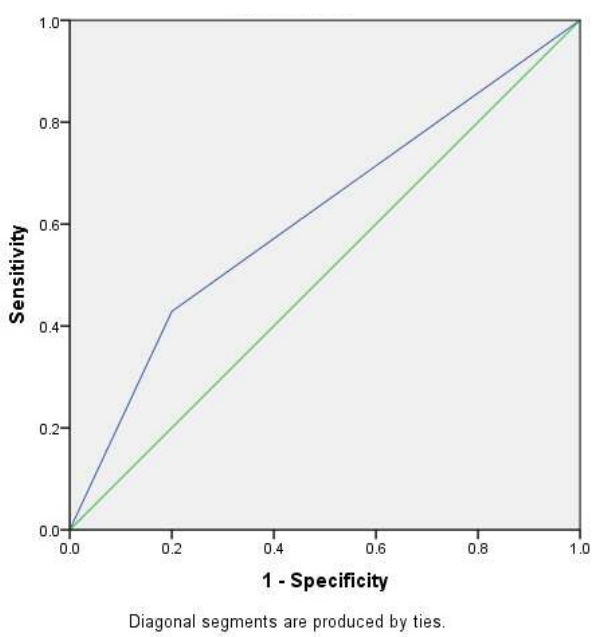

Figure 4. Receiver Operating Characteristic (ROC) Curve to assess TTF-1 performance in distinguishing EGFR mutations and wildtypes in adenocarcinoma patients

The analysis showed that the value of Area Under Curve (AUC) was 0.614 or $61.4 \%$. This figure shows that TTF-1 examination has moderate power in determining EGFR mutations. The interpretation values are: AUC $>50.0-$ $60.0 \%$ means very weak, $>60.0-70.0 \%$ means moderate, $>$ $80.0-90.0 \%$ means good, $>90.0-100.0 \%$ means very good.

\section{DISCUSSION}

\section{EGFR Mutation Frequency}

The results showed that patients who experienced EGFR mutations were 16 people $(61.5 \%)$ of 26 patients and wildtype were as many as 10 people (38.5\%) of 26 patients. Among these mutations, there were 16 patients with EGFR mutations. The division of these mutations shows there were 8 people who had mutations in exon 21, and there were 6 people who had mutations in exon 19, 1 person who had a mutation in 2 exons simultaneously (exon $21,20)$, and 1 person who had a mutation without being known in what exon. While, there were 10 people without mutations or Wildtype, as presented in Figure 3. This is in accordance with the previous findings. There are three types of mutations of EGFR that are often found, among others: (1) deletion in exon 19, which is the most common mutation that is about $46 \%$ of all EGFR mutations, (2) mutations in exon 18,20 , or 21 that are the second most common mutations, about $41 \%$ of cases of all EGFR mutations, (3) duplication/insertion in exon 20 (Chen, 2013; Roengvoraphoj et al., 2013; Siegelin et al., 2014; Shi $Y$ et al., 2014). Based on the literature, it is stated that the mutation rate of EGFR varies regionally. The mutation rate in the NSCLC in Asian countries is higher than that in western countries which is around $50 \%$, while in western countries, it is around $10 \%$.

Relationship between Pulmonary Adenocarcinoma and TTF-1 Examination

The examination results showed negative TTF- 1 in 5 people (19.2\%) of the study subjects totaling 26 people. Negative TTF-1 correlates with solid subtype and invasive pulmonary adenocarcinoma. This defines a subgroup of pulmonary adenocarcinomas with unfavorable outcomes. In addition, multiple metastatic recurrences are more 
likely to occur in adenocarcinoma patients with negative TTF-1.

Relationship of Thyroid Transcription Factor-1 (TTF-1) expression and Epidermal Growth Factor Receptor (EGFR) mutation, sensitivity, specificity, accuracy, positive predictive value, negative predictive value of TTF-1 expression against EGFR mutations

The Chi-square test found no significant relationship between the results of TTF-1 examination with EGFR mutations ( $p: 0.614$ ) with an odds ratio of 0.333 , while the studies of Sun et al. (2012) and Wang et al. (2014) revealed that there was a significant relationship between TTF-1 and EGFR.

This study also saw the sensitivity, specificity, accuracy, positive predictive value, negative predictive value of TTF1 expression against EGFR mutations. Based on the analysis results, it was found that the sensitivity of the TTF-1 examination was $75 \%$ and the specificity was $10 \%$. A sensitivity value of $75 \%$ indicates that of 100 people with EGFR mutations, TTF-1 can detect an EGFR mutation of $75 \%$. A specificity value of $10 \%$ TTF-1 indicates that of 100 people without EGFR mutations, TTF-1 can detect EGFR without mutation of only $10 \%$. A positive predictive value

\section{REFERENCES}

1. Ilonen I. Non-Small Cell Lung Cancer: Studies On Pathogenesis, Tumour Targeting and Treatment Outcomes. [Dissertation]. University of Helsinki, Finland. 2011.

2. Jusuf A, Syahrudin E, Agun W, et al. Kanker Paru: Pedoman Diagnosis \& Penatalaksanaan di Indonesia. Edisi Revisi III. Jakarta: PDPI; 2011.

3. Syahrudin E, Wulandari L, Muktiati NS, et al. Uncommon EGFR Mutations in Cytological Specimens of 1874 Newly Diagnosed Indonesian Lung Cancer Patients. Lung Cancer: Targets and Therapy. 2018; 9: 25-34.

4. Pan JB, Hou YH, and Zhang GJ. Correlation between EGFR Mutations and Serum Tumor Markers in Lung Adenocarcinoma Patients. Asian Pacific Journal of Cancer Prevention. 2013; 14(2): 695-700.

5. Yamaguchi T, Yanagisawa K, Sugiyama R, et al. NKX21/TITF1/TTF-1-Induced ROR 1 is Required to Sustain EGFR Survival Signaling in Lung Adenocarcinoma. Cancer Cell. 2012; 21(3): 348-361.

6. Jazieh $A R$, Sudairy RA, Shraie NA, Suwairi W, Ferwana M, and Murad HM. Erlotinib in Wild Type Epidermal Growth Factor Receptor Non-Small Cell Lung Cancer: A Systematic Review. Annals of Thoracic Medicine. 2013; 8(4): 204-208.

7. Al Olayan A, Al Hussaini H, and Jazieh AR. The Roles of Epidermal Growth Factor Receptor (EGFR) of $57 \%$ means that out of 100 patients with a positive TTF1 , only about $57 \%$ have an EGFR mutation. A negative predictive value of $20 \%$ means that out of 100 people with TTF- 1 is negative, around $20 \%$ of EGFRs are completely not mutated. The ROC curve presented in Figure 4 shows that the Area Under Curve (AUC) value is 0.614 or $61.4 \%$. This figure shows that the TTF- 1 examination has moderate power in determining EGFR mutations.

TTF-1 is not only an important cell marker of adenocarcinoma but also provides significant guidance for doctors to take a reasonable and timely plan for therapy with advanced pulmonary adenocarcinoma, especially for advanced lung cancer (Asians, women, adenocarcinomas, non-smoking) who can get timely maintenance. As a marker, the combination of EGFR mutations with positive expression of TTF-1 can guide the diagnosis and effective clinical therapy.

\section{ACKNOWLEDGMENT}

The author would like to thank profusely to all those who helped in the writing of this journal. Hopefully, it is useful for the advancement of science and especially for patients in getting the right and timely treatment.

Inhibitors in the Management of Lung Cancer. Journal of Infection and Public Health. 2012; 5(1): 550-560

8. Bethune G, Bethune D, Ridgway N, and Xu Z. Epidermal Growth Factor Receptor (EGFR) in Lung Cancer: An Overview and Update. Journal of Thoracic Disease. 2010; 2(1): 48-51.

9. Listyoko A, Herman, and Prasetya F. Profil Kanker Paru di RSSA 2015. Malang: RSSA; 2017.

10. Pan YQ, Shi WW, Xu DP, Xu HH, Zhou MY, and Yan WH. Associations between Epidermal Growth Factor Receptor Gene Mutation and Serum Tumor Markers in Advanced Lung Adenocarcinomas: A Retrospective Study. Chinese Medical Science Journal. 2014; 29(3): 156-161.

11. Chen Y. Update of Epidermal Growth Factor Receptor-Tyrosine Kinase Inhibitors in Non-Small-Cell Lung Cancer. Chinese Medical Sciences Journal. 2013; 76: 249-257

12. Roengvoraphoj $\mathrm{M}$, Tsongalis GJ, Dragnev $\mathrm{KH}$, and Rigas JR. Epidermal Growth Factor Receptor Tyrosine Kinase Inhibitors as Initial Therapy for Non-Small Cell Lung Cancer: Focus on Epidermal Growth Factor Receptor Mutation Testing and Mutation-Positive Patients. Cancer Treatment Reviews. 2013; 39(8): 839-850.

13. Siegelin MD and Borczuk AC. Epidermal Growth Factor Receptor Mutations In Lung Adenocarcinoma. Laboratory Investigation. 2014; 94: 129-137. 